\title{
'A Last Resort and Often Not an Option at All': Farming and Young People in Ethiopia
}

\author{
Getnet Tadele and Asrat Ayalew Gella
}

Abstract Development policies in Ethiopia emphasise agriculture as the pathway to industrialisation. Policies allude to the need for a new generation of young, literate and trained farmers to transform the agricultural sector and bring about the required growth in agricultural output. The success of this strategy largely depends on the willingness of the new generation of literate rural youth to take up agriculture as a potentially rewarding livelihood. This article investigates, based on fieldwork conducted in two rural kebeles of Ethiopia, whether young rural people have this willingness to take up agriculture. It examines the factors that contribute to both the desirability (and undesirability) of agriculture as a future livelihood. Findings revealed that very few young people and their parents were considering farming as a possible option for a future livelihood. For others, farming/agriculture might be a last resort.

\section{Introduction}

The government of Ethiopia considers agriculture as the key sector in the success or failure of its national development. According to the latest five-year 'Growth and Transformation Plan', growth in the agricultural sector, in addition to meeting food security targets, is expected to provide the vital push to jumpstart the rest of the economy (FDRE Ministry of Finance and Economic Development 2010). The government considers improving agricultural skills, knowledge and productivity a vital component of the agricultural development strategy, in the belief that not much can be achieved through trying to teach the older generation of farmers who are unable and/or unwilling to acquire and adopt new, improved and scientific methods of farming. Various policies emphasise the need to cultivate a new generation of literate farmers (preferably with post-elementary school agricultural training or, at the very least, who have completed elementary school). According to the Agricultural and Rural Development Strategy (FDRE Ministry of Information 2002), literate farmers are needed for improved agricultural innovation and output which in turn will allow young people to secure more productive and attractive employment in agriculture. Reflecting on this policy, this article attempts to capture attitudes and aspirations of rural in- and out-ofschool young people towards agriculture.

Leavy and Smith (2010) argue that there is a blurred boundary between aspirations and expectations and suggest that aspirations need to be understood in line with their determinants. They note that young people's aspirations in subSaharan Africa are influenced and ultimately formed by existing broader social and economic circumstances. Young people's aspirations and expectations in relation to economic outcomes are strongly related to sociocultural influences and the degree of social embeddedness. Social influences on aspirations tend to be stronger in rural areas resulting in social pressures that encourage uniformity and limit student achievement regardless of aspiration and motivation to succeed. There is a tendency for rural young people's educational expectations to be lower than those of their urban counterparts. Higher poverty rates and lower socioeconomic status in rural communities negatively impact on the aspiration levels of young people. Aspirations are not just about economic opportunity - status is important: agriculture is unappealing to young people because it does not bring status 
regardless of economic outcomes. Thus, occupational aspirations not only depend on tangible outcomes such as income or standard of living that accrues from occupation, but also intangible benefits such as prestige and status in society. Lack of prestige is one of the reasons why agriculture is not attractive to young people regardless of the economic outcome. Engaging in agriculture in one's own community (in the presence of significant others), particularly after going through schooling, is perceived by young people as degrading. However, manual labour performed in other locations does not affect status in the same way and such absentee work can enable young people to acquire life skills and funds for self-employment and social and kinship contributions that confer higher status (Proctor and Lucchesi 2012).

There is often a disconnect between young people's aspirations and the reality on the ground. For instance, African secondary school students' vocational aspirations and expectations do not reflect the employment opportunities or the realities of the labour market, or the socioeconomic conditions and development levels of their countries (ibid.). Given that agriculture in general, and small-scale farming in particular, is key to the country's economic growth both now and in the foreseeable future, understanding aspirations of the future generation of farmers and whether they are attracted to take up agriculture as a livelihood is critical for any interventions around agriculture in Ethiopia.

This article explores characteristics of 'agricultural life' which make it desirable or undesirable to young men and young women across educational levels and regions and the major forces shaping young men and young women's perceptions of 'agricultural life' and life aspirations more generally.

Fieldwork was conducted in two regions: Amhara Region, East Gojjam Zone - Gozamin Woreda (Chertekel Kebele); and Southern Nations, Nationalities and Peoples Region (SNNPR), Alaba Tembaro Zone, Qedida Gamella Woreda (Geshgolla Kebele). The sites have contrasting agro-ecological zones and farming traditions, cultures and orientations. Geshgolla Kebele is more oriented to cash crop production than Chertekel Kebele and school enrolment appears higher. Land shortage is much more severe in the Geshgolla: most households have

landholdings of 1 or 2 timads $^{1}$ or less, the wored $a^{2}$ being the second most populous in the country. ${ }^{3}$ The area is becoming increasingly prone to food insecurity with successive years of irregular seasonal rains: a number of farmers interviewed were more or less dependent on the government Productive Safety Net programme.

Focus group discussions (FDGs) were carried out with older farmers (men and women), young farmers (men and women), school students in grades 7 and 8 (aged around 16-18 years) (boys and girls), and young people who have left school but are not farming (boys/men and girls/women, in some cases college students, aged around 20-25 years). Fourteen FGDs were conducted with 99 participants across the two sites. Key informant interviews were conducted with officials from woreda agricultural offices, development agents (DAs) and kebele officials.

\section{Perceptions of farming as a way of life}

'Meretu hamsa kind berew yetewiso;

Indet libela new indih hono tarso',

- Words from a popular folk song

The farmer was described variously as 'someone who labours to feed others'; tied to his land; and lacking, participants perceived, any other option than simply being a farmer. ${ }^{5}$ While an educated man was seen as being able to move about freely, work wherever he wanted and live where he wanted to live, the farmer was tied down to the same place and to the same trade - toiling his land. 'What else can a farmer do? What else can he be? He is already all he can be, he has nothing but his land and his labour. He can't say: I am done being a farmer and move on. He has no options' (older farmer, Chertekel Kebele). The farmer was described as someone who, through his own labour, feeds not only himself but others. The farmer was held up by many participants as the base upon which all life is built, the source of food and hence the source of life. ${ }^{6}$

Life as a farmer was tied to life in a village which most respondents saw as hard and demanding. Referring to this perception, a key informant from the Woreda Agriculture Office (Chertekel Kebele) remarked 'People still don't realise that one can live in a village and yet live a good life. Even when you find the odd young person who has gone into agriculture after failing to pass the 
national exams (at grade 10), and they succeed and lead a good life, people still refuse to see their success. They don't say "so and so's son has become a good farmer". They would rather say "So and so's son became a farmer after all those years of education"'. Agriculture is still seen as a degrading occupation - especially when someone is educated. 'Even the agricultural extension workers (DAs) are often ashamed of their own occupation. You will find them reading accounting books under their desk trying to get a job in some office as soon as they possibly can' (ibid.).

While life as a farmer was described in more or less the same terms in both sites, farmers in Geshgolla Kebele did not see themselves as farmers per se. Although farming was by and large their main livelihood, the fact that they have so little land caused them to question the extent to which they could claim to be proper farmers. As one farmer put it,

We are only farmers by name. In the olden days, there were not as many people, land was plenty, and we had plenty of cattle. But this is no more. There is no land, there are no cattle, whatever people had, they lost due to drought. We simply continue calling ourselves farmers, without any land and without any cattle.

The lack of farmland was repeated over and over. Only one of the participants had four timads of land and was considered an exception in the kebele, where having two timads was considered above average.

Say you had something like two hectares of land, a pair of oxen, and were able to grow five or more different crops. You could live well off that, feed your children and send them to school and you certainly call yourself a farmer. But no one here has that kind of land any more (male farmer, Geshgolla Kebele).

Yet life in farming was seen as appealing by many participants; though only under certain favourable circumstances. The fact that the farmer is not dependent on anyone, lives from his/her own efforts, and even provides for others was seen as an attractive feature of agricultural life. The farmer is independent, self-reliant and free, lives off what he/she produces, does not depend on others and does not pay for food, wood or water. The farmer is his/her own boss, does not have anyone saying what must be done. $\mathrm{He} /$ she works and rests as appropriate.
The farmer was also seen as hard working, well behaved and decent - unlike town folk who are often perceived as 'immoral and wicked'. The farmer spends his day with his oxen and with the soil, and hence stays away from things that corrupt mind and body (such as drinking and promiscuity). The farmer was also described as, at times, simple minded and perhaps ignorant of much other than that which goes on in his own life. Although this was considered a shortcoming in some ways, some participants were keen to stress that the farmer lives a purer, simple life (FGD, male farmers).

But life as a farmer now was described as far from ideal and becoming increasingly difficult. Decreasing crop prices and a sharp increase in the prices of fertilisers have made life not only demanding but increasingly frustrating.

Farmers, young and old, and key informants in both sites stated that land was not only becoming scarce but also losing its fertility, with increasing dependency on fertilisers to produce anything. 'We can understand an increase of 100 birr, or even 200 perhaps. But 400 birr? That is almost as if the government is trying to kill us', one farmer from Geshgolla Kebele complained. The increase in the price of fertilisers was seen as particularly unfair in a year when crop prices have declined. Problems with the availability, quality and price of improved seeds were seen as a further challenge to viable agriculture.

The greatest barrier to realising a good life through agriculture was seen as land availability. With land becoming increasingly scarce, land disputes were causing numerous conflicts, even between parents and children and among siblings, in both sites. One of the participants from Chertekel Kebele was in the area to follow up on a court case after being beaten nearly to death from an argument arising from a land dispute. Another farmer had two sons in hospital due to injuries sustained from a similar landrelated quarrel. Officials from the Woreda Agricultural Office in Geshgolla Kebele confirmed that most of the conflicts (usually among siblings and relatives) in the area are caused by disputes over land ownership.

\section{Recent changes in farming and its appeal to young people}

According to participants in both sites, agriculture has changed significantly over the last decade, 
particularly in the last five years. There seems to be consensus on this across respondent groups. Although the basic techniques of farming (use of ox-drawn ploughs) and the type of farming (mixed farming) have remained basically the same, the introduction and adoption of agricultural inputs such as improved seeds, fertilisers and better farming methods (such as slash ploughing, sowing seeds in rows, water pumps, modern beehives) has produced significant increases in productivity. Older and younger farmers gave examples of how they have been able to get more out of their land as a result. Participants in Chertekel Kebele narrated how getting 12 quintals of wheat from a hectare of land used to be considered a blessing but it was now quite usual to get up to 40 quintals of produce from the same land. Improved farming methods such as modern beekeeping hives and methods have also produced gains: one farmer reported earning twice as much from a single modern beehive as he had before.

On the question of whether agriculture was becoming more desirable to young people as a result, there were competing narratives. On the one hand, participants felt that these developments were making agriculture more and more profitable and therefore more appealing. But they felt that there was a huge obstacle negating this appeal - scarcity of land. The young, all participants emphasised, have no land of their own and no means of obtaining any which was discouraging them from even considering agriculture as an option. ${ }^{7}$ One young male farmer remarked that many young people are interested in going into agriculture since farming is the tradition and the most natural thing for them to do, but decide to explore other options such as trade and business when the option of becoming a farmer is closed off because they cannot get land. He added that farming would not be an occupation to be lamented and despised if it was not for the shortage of land. Another participant from Chertekel Kebele went further, saying the government has simply abandoned young people; they have not been given land so they cannot go into agriculture, but neither is the government giving them other opportunities for making a living. Although some measures are being taken by the government to organise the unemployed youth and help them create jobs for themselves, the participant observed, this was only so in towns. The rural youth were simply left to fend for themselves. ${ }^{8}$
Although the dominant view was that young people are disinterested in agriculture, some participants pointed out that this was not always the case. One young male farmer in Chertekel Kebele explained:

If you are a good farmer, use improved seeds and know what to cultivate, you can be better off than a salaried government employee. Farming is very profitable, and you can make a lot of money. Even town people have come to realise this and are coming into agriculture as 'investors'. And many young people would rather go into farming than try something else. But like my friends here have said, they have no land. They have the desire, but the desire alone is not enough: they need land but land isn't easy to get. So they start thinking of other things they can do or some migrate somewhere else thinking there is nothing they can do here. But there are also some young people who, after completing school and failing to go to college, feel it is degrading to go back to farming. They see their parents and their friends who are farmers, they live a life of hard work, they have no rest, they live with the mud and dirt, even their clothes are full of dirt and mud. And then they see town people with clean clothes and smooth faces and they think that is better.

Thus, improvements in agricultural incomes experienced by some have not made farming universally more appealing.

\section{Attitudes to farming across age, education and gender}

The desirability or undesirability of agriculture as a way of life appeared to vary to some extent with age, gender, level of education and notably whether the young person was still in school or had left school.

\subsection{Young people still in school}

Young boys and girls currently attending school were more inclined to view agriculture as a dead end: an option they were either unwilling to consider at all or only as a last resort. Although a few children saw a future in farming as a second best option if their education failed to lead anywhere, school students had a generally negative attitude to the possibility of going into agriculture, even if they failed to pass the national school-leaving exams. Most of the young people interviewed said they could not see themselves going into farming since they had neither the desire nor the means to do so. One schoolboy from Geshgolla Kebele, for example, 
explained that his family has only four gemeds of land and even this had been divided up by two of his three elder siblings who had already completed school and have become farmers. He simply had no way of becoming a farmer even if he wanted to, as his family didn't have any land to give him. But even if this was not the case, farming was not a way of life he would choose: 'God willing, I will be able to continue with my education to college and make something out of myself. That is my only hope'. Similar views were expressed by other school students, frequently with the phrase 'make something of myself through education', which obviously excluded any possibility of becoming a farmer and seemed to mean becoming 'anything but a farmer'.

That they were currently in school and therefore still had hopes and aspirations of pursuing their education further to 'make someone out of themselves' appears the most important factor behind this generally negative attitude towards a future in agriculture. As one 16-year-old school boy in Chertekel Kebele put it:

If we were not attending school, we wouldn't have had anything to aspire to besides our parents' livelihood and their simple tools (maresha, misar and wubar). But we have come to know that there is more to life than that and it is all because of our education.

For many young people still in school, the life of the farmer was perceived as tiring and hard, a life of endless toil with little gain. The farmer was seen as having no goals in life and no plans, living off what they get from the land - starving or feasting as the produce comes. Even when the farmer enjoys a rare good harvest, this gain never goes beyond the year as they do not invest it in anything that may bring more gains. They also described the farmer as traditional and 'ignorant', out of touch with the modern world and stuck in tradition (FGDs with young people in both sites).

\subsection{Girls attending school}

This negative attitude towards any future life in agriculture was even more pronounced among girls attending school. The girls described the lives of their parents as traditional and backward and said they wished for a better life which they hoped to attain through their education. One phrase repeatedly used by the girls was 'kegibrina hiwot melaqeq' - 'getting far away from a life in agriculture', in other words, that of their parents:
They know little, they go about their lives based on what they know from tradition and that is not a life I want for myself. I have got to be better than that and that is why I am attending school. Farming is not something I wish for (schoolgirl, Chertekel Kebele).

Although she added that not all farming is traditional and backward and there exists another type of 'modern farming', the farming practiced by her own family was far from this. Another girl said she often sees her parents going about doing things in the wrong way which often frustrates her:

But when I try to suggest things to them, all I get is insults. So I don't do that. Rather I simply hope that I myself don't have to live my life like that.

The girls described how life as a farmer's daughter was hard and demanding enough.

I come from school and I don't get any time to study. It is do this, do that. We all have to do household chores late into the evening. Perhaps we might get an hour or so late in the night to look at our exercise books but even then our parents may think we are wasting the lamp. I wish I had more time to study, I wish my parents understood that I needed time for my education. I wish they could allow me to plan my time and put aside some of it for work and some of it for study. But they don't understand this. It is hard. Sometimes it frustrates me. If it this hard already, it can only be worse if I become a farmer like them (schoolgirl, Chertekel Kebele).

Like the boys, the girls felt that they have come to see how backward and traditional the lives of their parents are, as a result of their education. One schoolgirl from Chertekel Kebele remarked, 'We don't think like them, we want a life that is better than theirs. So we don't really get along.'

Education, the girls believed, has shaped their views - to look beyond and above the traditional to what they considered was the modern way of life.

Although education and the disconnect with their family lives appeared to be the major factors shaping the girls' rejection of a future life in agriculture, shortage of land discouraged them even further. One of the schoolgirls from Chertekel Kebele described how her older sisters and brothers who have become farmers have to go to exceptional lengths to get any land to cultivate. 
They don't have any land of their own - they had to literally hunt for land they can work on - land owned by other people. They work on it and have to share their produce with the owners. ${ }^{9}$ But even such land is not easy to find. And how can I possibly want to go into farming when I see my own sisters go through all this trouble to get a plot of land to work on? Living off agriculture is just too difficult.

The girls also referred to tradition and the gendered allocation of tasks as making their lives particularly difficult although, they were keen to stress, there was nothing a man can do that a woman can't.

There is this tradition that has been carried over from the past. For example, you will never see a man baking injera or cooking; or a woman ploughing land or sowing seeds in the farm. It is just tradition, but it keeps men and women doing different things (schoolgirls, Chertekel Kebele).

This division of labour, which the girls believed unnecessary, serves to keep women dependent on men.

Even if a woman had her own land but no husband, she can't farm it herself. Maybe she can lease it to someone who can but she can't go out with a plough and a pair of oxen to actually cultivate it herself.

Aside from this gendering of work, the girls believed that the life of the farmer was similar for both men and women - it was hard for both.

\subsection{Young people out of school and not farming}

A slightly more positive attitude towards agriculture was evident among young people who have left school, either failing to complete high school for various reasons or to qualify for higher level education. ${ }^{10}$ Although this group of respondents were equally keen to point out what was, in their opinion, so wrong about traditional agriculture and the life of the common farmer, a number of them were not as quick to dismiss agriculture as a possible future livelihood, while a few even saw it as a preferred livelihood option, if conditions were to be improved.

In both sites the most important factor preventing school-leavers from even considering a life in agriculture as a possibility was the lack of access to farmland, rather than lack of interest. For some, particularly young men, farming was seen, at least for those who were educated and had skills, as quite an attractive option. The young people clearly distinguished between traditional farming, which they viewed as backward and unappealing, and modern improved farming. 'If I had land, I wouldn't waste it producing cereals', one stated. 'Even a small plot can earn you a lot of money if you planted gesho ${ }^{11}$ on it'. Farming, provided one had a good piece of land preferably with access to an irrigation source such as a stream or a river, was seen as a very lucrative business. One young out-of-school man from Chertekel Kebele remarked, 'I bet I could turn my life around in just two years [if I had such land]. But there just isn't any land.' Another pointed to the example of a cousin:

\section{He only has one gemed of land that he got during the 1998 (EC) redistribution. But even with that he is making a good living. He planted gesho and qhat on it and recently got 7,000 birr out of selling gesho seedlings alone. So ifyou know how to go about it, farming can be as good as or even better than anything else. But there just isn't any land for us - and what sort of a farmer can you be without any land?}

When asked if they have ever considered subleasing land or sharecropping (metemed) from others since they thought farming was lucrative, young out-of-school men said that this was not an attractive option. Opportunities for sub-leasing were said to be very limited as land had already been taken by other people who do not have a plot of their own. Even when the possibility exists, this arrangement was described as 'not worth the effort'.

You work and sweat and end up giving almost half of what you have produced to the owner of the land. Perhaps you can make a meagre living out of this but it certainly wouldn't be enough to change your life. It is not as appealing as having your own land' (ibid.).

Participants noted a disconnect between the vision of securing a good life from farming and the reality of the majority of people's lives in their locality.

I know that farming shouldn't necessarily be like this. I have been taught in school that agriculture can be modern, and that it can be a very profitable business. That it is the backbone of our economy and that through modern agriculture we can change not only our own lives but even the economy of our country. But 
that is all in class. I look around and I see no one who has been able to better their lives through agriculture (young out-of-school man, Chertekel Kebele).

Others, referring to what they saw as the overwhelmingly negative attitude among the young towards agriculture as a potential livelihood, offered an explanation:

We go to school as children and come to know many things by the time we finish. Once done with school, there are a lot of young people who think that going back to farming is like accepting defeat; it is like admitting you can't be anything better than your parents. All those years gone into education, all the effort you put into it, it all comes down to nothing and it shames them.

But this, they stressed, need not be the case. If they themselves went into agriculture, they reasoned, they would not necessarily share the same fate since they were better educated and better able to make the best out of farming (young out-of-school men, Chertekel Kebele). A similar sentiment was expressed by school-going girls and boys.

\subsection{Parents}

Negative attitudes towards agriculture were not exclusive to the young. Although older farmers and officials were quick to lament that young people were too lazy and arrogant to acknowledge that agriculture can be a very lucrative livelihood, none wanted their children to follow in their footsteps. This was the case even for those who claimed their lives had improved and that agriculture was now as good a livelihood as any other, if not better. As one middle-aged male farmer in Chertekel Kebele put it:

Our hope is that our children will be able to make something of themselves through their education; that they can become someone we would be proud calling a son or daughter; that they live better lives and perhaps even support us to live better. Why else would we send them to school? So they end up exactly like us.? How can they be farmers anyway [even if they wanted to] when land is as scarce as it is?

Even the successful young farmers from Geshgolla Kebele who said they 'thanked God' for making them farmers instead of civil servants did not want their children to become farmers. One participant concluded:
Our children have two choices - either they go on with their education and find employment or, if they fail, they can borrow money from somewhere and go into trading and business. Farming is not a realistic option - and even if it was - it is not something we wish for them.

It is therefore unsurprising that young people are turning against agriculture since aspirations of the young are framed within the implicit and explicit expectations placed upon them by family and kinship networks (which in turn are influenced by gender-based societal customs and norms) (Leavy and Smith 2010).

\section{Government perspectives and responses}

The government of Ethiopia has been pursuing an Agricultural Development Led Industrialisation Policy (ADLI) for over a decade. Growth in the agricultural sector is sought not only for its own ends (achieving food security) but also to provide the vital push the rest of the economy needs to 'jump start' it. The need to motivate the rural labour force, especially the young, and ensure its commitment and strength to strenuous agricultural work is discussed at length in the agricultural and rural development strategy.

Rural educated youth are seen as presenting a challenge, as they may not consider the agricultural sector a viable or desirable means of livelihood; yet it is vital for them to do so (FDRE Ministry of Information 2002). Apart from the inability of the urban economy to accommodate a huge influx of labour from the rural agricultural sector, the government considers rural educated youth as instrumental in bringing about a transformation in agricultural skills, knowledge and productivity. The Rural Development Strategy (ibid.) therefore calls for an aggressive approach to tackle negative attitudes, believing that no rural development policy will succeed with a mindset equating agriculture with backwardness. It emphasises the vital role of schools (which it says are partly responsible for the development of this mindset) in inculcating the inherent value of work, including agriculture, in students, especially during primary education. But this alone is recognised as unlikely to be very effective. A new generation of educated and trained farmers needs to be able to earn a level of income at least comparable to those with similar education in other sectors; achievable only by increasing the per capita productivity of farmers (ibid.). 
Rural development programmes such as rural electrification and the expansion of education and health care have also been designed to improve the lives of people in rural areas. Within the agriculture sector, under the government extension programme, farmers are supposed to get all the support and technical advice they need from the DAs based in each kebele.

It is quite difficult to assess how far development policies aimed at the agriculture sector have been translated into action and what effects, if any, these have had on young people going into agriculture. Agricultural extension workers, woreda level agricultural experts and young and older farmers appear to agree that substantial gains in productivity have been achieved over the last decade as a result of the introduction of high-yielding varieties and greater fertiliser use and adoption of improved farming techniques. Although some of these gains have been lost in the last two years in Geshgolla Kebele due to successive years of poor rains, it appears there have been some improvements in the lives of many farmers, especially in Chertekel Kebele.

However, the agricultural modernisation programme has not been an unreserved success as farmers (and some officials) point out, particularly the unaffordability of improved inputs, and high-yielding seeds which have failed to produce. A programme promoting crop specialisation appears to be having mixed success. In Geshgolla Kebele, where there is greater land pressure and higher cash cropping, woreda agricultural officials narrated how kebeles suited to coffee, maize and wheat are being identified and farmers encouraged to go into these crops. In Chertekel Kebele there has been little progress with the specialisation policy, despite the insistence of officials that lowland (qolla) areas are well suited to sesame, coffee and sugarcane; the agriculture practised there remains heavily geared towards livestock. Highland (dega) areas were more appropriate for rearing sheep than producing teff (since the soil has become too infertile due to years of erosion and intensive farming) but the agriculture practised there remains mixed at best.

In the eyes of agricultural officials at woreda and kebele levels, while the older generation of farmers is taking advantage of opportunities offered to maximise productivity, the younger generation, particularly high school leavers, continue to regard agriculture as a degrading profession and beneath them. Some felt that not enough is being done to challenge what they regarded as the 'misguided' attitudes of the young towards agriculture:

\section{Someone needs to talk some sense to these young people. They have no problems wasting their young lives and energy working as daily labourers and earning money that is just enough to cover their meals. Why they think agriculture is beneath them is beyond comprehension! They could make a better life for themselves, assist their families and contribute to the country's development. But they don't see that (key informant, Woreda Agriculture Office, Chertekel Kebele).}

The solution, according to the official, is to talk to these young people, to make them realise that agriculture is not the evil they think it is and to help them get a better life as 'educated and modern' farmers. While uneducated youth who stay in their villages are seen as making use of extension services, those who have gone to urban centres and towns for high school and stay there after failing to enter higher education are being forgotten by the government.

Local officials concurred that access to land was an obstacle to young people pursuing agriculture as a livelihood, particularly in Geshgolla Kebele, with meagre family landholdings and no uncultivated communal land, and saw voluntary resettlement as the only way of giving any land to the young. They acknowledged young people were not being prioritised in the resettlement programme which focuses on relocating families currently dependent on the Productive Safety Nets Programme. Even in Chertekel Kebele, with less intense pressure on land, young people had little or no access to farmland due to the regional government ruling against further land redistribution (on the grounds that this would lead to further fragmentation). This leaves young aspiring farmers with only two options: getting land from their own families (considered unlikely since any land has already been taken by older siblings) or securing a plot from the communal grazing fields, which requires the consent of at least 80 per cent of households in the area; and this is, according to local officials, often impossible. On the other hand, local officials pointed to land swaps 
through inheritances (often gained through divorce and remarriage) and increasing land concentration in the hands of a few households. Some even drew parallels with the old imperial days when land was owned by a few landlords. Problems of access to land by young people were said to be exacerbated by patronage-based land distributions favouring members of the political elite.

These perceptions have contributed to a sense of injustice and deprivation among young people, especially those who are already in agriculture and struggling to find plots and those willing to go into agriculture but unable to do so with no means of accessing farmland. Thus, it appears the government has not effectively addressed either the attitude of many young people towards agriculture or the obstacles preventing their entry into the sector.

\section{Is agriculture a future for young people at all?}

Despite recent productivity improvements, the prevailing attitude among many young people is that agriculture is backward, demanding and even demeaning - especially for those who have gone through years of education with higher hopes and expectations. Within the context of negative attitudes of family and society about agriculture, informal work in urban areas is preferred by young people who have attended school even if it is lowpaying and as back-breaking as agriculture. Going back to agriculture after failing the national schoolleaving exams is seen as a defeat. Even when young people are willing to face up to the humiliation of going back to a life in agriculture after years of schooling, they find it almost impossible to get hold of a plot of land they can farm. The young people interviewed in this study, both male and female, in and out of school, said that the only potential livelihoods options open to them were some form of employment through their education, manual labour in towns, the service industry (such as waitressing) or petty trade.

In addition to negative attitudes and the shortage of land, the steep increase in the price of fertilisers, increasingly erratic and unpredictable nature of seasonal rains (perhaps due to global warming), loss of soil fertility due to the erosion of topsoil and its increasing acidity, were all mentioned as factors not only making agriculture less appealing to the young but also increasingly difficult for farmers.
Prevailing assumptions and policy prescriptions aimed at cultivating a new generation of literate farmers need to be challenged, as literate young people (and their parents) are unequivocally against the idea of them engaging in agriculture. New debate is needed on whether policy discourses are in line with the aspirations and demands of young people and rural realities.

This requires finding ways of engaging rural youth in the policy process and addressing what needs to be done to make farming more attractive as a livelihood. Mass media and education may have a proactive role to play 'in influencing young people and their parents to view agriculture as a respectable and rewarding livelihood'. Practical steps are needed in parallel to make agriculture a realistic future career. Access to land was the top concern for young people in both sites studied, and the government needs to consider how to facilitate land acquisition for young people interested in agriculture. Rural areas in Ethiopia (in common with most developing countries) have remained underdeveloped in terms of infrastructure and other facilities and thus not conducive to attracting and retaining young people. Although improvements have been seen in the past decade, the young still feel that agriculture and rural life is backward. Addressing infrastructural needs of rural people and catalysing the social and economic transformation of rural areas would, in the long run, be likely to attract young people to engage in agriculture.

Although agricultural systems and farming traditions have changed little, there has been a marked improvement in productivity with the use of high-yielding varieties and fertilisers. But the gains from the past decade are slowly eroding due to recent difficulties caused by erratic rainfalls and the drastic increase in input prices, both of which seem to be dampening young people's expectations of a successful future life in agriculture.

The private sector, which is engaged in supplying agricultural inputs and technologies in rural areas, also has a role to play in encouraging young people's participation in the agri-food sector and could be encouraged through incentives to show corporate social responsibility, for example, supplying inputs to young farmers on credit (at low interest). 
While the government has made some attempt to engage with urban youth and create employment opportunities through micro and small-scale enterprises, very little attention has been paid to rural youth. There are a number of possible reasons for this. First, rural unemployment or underemployment is disguised or concealed because of the nature of the rural economic sector. Second, urban unemployed youth are considered a social and political threat. Thus, any actions taken to support rural youth are essentially to prevent rural-urban migration and reduce such threats. Government efforts often appear as knee-jerk reactions rather than considered policies directed at creating decent employment opportunities in agriculture and other rural sectors.

Although some progress has been made in encouraging young people to go into agriculture through actions such as rewarding model farmers, the many negative voices captured in this study do not inspire confidence that enough has been done to attract young people into agriculture as a livelihood. And it is not only rural young people who are rejecting farming as a livelihood but also their parents, including those with successful agricultural enterprises. There is a long way to go if young people and their parents are to 'unlearn' their negative perceptions of agriculture. This involves re-establishing agriculture not as a last resort but a sector that can provide viable livelihoods, valued by society and essential for national food

\section{Notes}

1 Gemed or timad is a local unit for land measurement that is often translated as corresponding to 0.25 hectare. There is, however, some diversity in its use and a timad/gemed can range from 0.16 to 0.25 hectares depending on the locality and the type of soil. It is important to note here that in its literal meaning, a timad of land is equal to the amount of land that can be ploughed by a single farmer using an ox-drawn plough in a single day. Both terms were used interchangeably by our informants.

2 Woreda, or districts, are the third-level administrative divisions of Ethiopia and are managed by a local government. A kebele is the smallest administrative unit of Ethiopia, a neighbourhood or a localised and delimited group of people. It is part of a woreda.

3 Most participants in this site had between 8-12 children. security. And any such intervention will need to take the heterogeneity of young people into account - in terms of age, gender, educational level or work status.

There is a pressing need to engage policymakers, development partners, academics, civil society organisations and the private sector in ways of meeting the aspirations of rural youth and arousing their interest in agriculture. Engagement and policy dialogue must take the perspectives, aspirations and needs of young people into account and engage them meaningfully.

At the same time, the very real practical constraints to young people taking up agriculture need to be addressed by policymakers. Foremost is access to land, which is effectively preventing young people from entering farming (in high and some less densely populated areas), even if they wish to do so. Addressing the intergenerational transfer of land and reopening the debate over the principle and practice of land redistribution (to limit patronage and enable young people to benefit) is becoming a matter of urgency to prevent ongoing conflicts over land escalating into large-scale instability in rural areas. Secondly, young people who wish to take up 'modern' farming, but do not have the capital to do so, need to be assisted through access to input programmes and credit. Otherwise, the government's vision of cultivating a new generation of elite young farmers will remain a mirage.

4 Words from a popular traditional song: 'I have only 50 hands of land [the measure of the hand from the elbow to the fingertips, i.e. 50 cubits] and even my ox is borrowed, how am I to feed myself and my family?'

5 This description of the farmer appeared frequently in group discussions with older farmers in both Chertekel and Geshgolla, and to a lesser extent in group discussions with youth.

6 It should be noted here that 'the farmer' was understood by almost all participants to be a man and described as such.

7 Over an informal discussion on the topic of the youth having no land, the deputy chair of the kebele administration in site one - himself a farmer - remarked 'it is the question they keep on raising in every meeting, they want land. But then again the government says land should not be redistributed again, that it 
will be too fragmented if redistributed every now and then.'

8 In an informal conversation with a young man in his early 20 s who said he was from a farming family and had completed school, it was learned that there were some attempts to organise the youth into enterprises by the woreda. 'They [woreda officials] come here and call us for a meeting. They tell us a thousand things about how we need to create jobs for ourselves and promise they will assist us in organising ourselves in groups and other things. They ask us what we want to do and write that down. And they leave saying they will be back on this day or that to take it up further. But when we come back on the day they gave us, they don't show up.'

9 This arrangement, called metemed or sharecropping, involves leasing the land and in return for farming the plot: the sharecropper gives a certain proportion (usually one third to half depending on the arrangement) of the

\section{References}

FDRE Ministry of Finance and Economic Development (2010) Five Year Growth and Transformation Plan of the Federal Democratic Republic of Ethiopia (2010-2015) [Amharic], Addis Ababa

FDRE Ministry of Information (2002) The Rural Development Policies and Strategies of the Government of Ethiopia [Amharic], Addis Ababa

Leavy, Jennifer and Smith, S. (2010) Future Farmers: Youth Aspirations, Expectations and Life Choices, IDS Discussion Paper, Brighton: IDS produce to the owners of the land. There are reports that 'renting or borrowing land is somewhat higher in Ethiopia and Ghana than in other countries' [in Africa or SSA] (Proctor and Lucchesi 2012: 44).

10 Leavy and Smith (2010: 7) maintain that 'aspirations tend to decline as children mature into young adults, in response to a growing awareness of the world, its possibilities and constraints, influenced by previous choices and experience'. However, Nwagwu (1976 in Leavy and Smith 2010: 7) argues that, 'in spite of awareness of tight labour markets and limited economic opportunities generally, students in countries like Nigeria and Kenya maintained high aspirations and high expectations for their future employment'.

11 The Shiny-leaf Buckthorn (Rhamnus prinioides) - used in the preparation of local alcoholic beverages in a manner similar to that of hops in beer production.

Nwagwu, Nicholas A. (1976) 'The Vocational Aspirations and Expectations of African Students', Journal of Vocational Education and Training 28: 71, 111-15

Proctor, Felicity and Lucchesi, V. (2012) Smallscale Farming and Youth in an Era of Change, London: International Institute for Environment and Development (IIED) 